\section{First report on occurrence of Babesia infection in Nilgai Boselaphus tragocamelus from central India}

\section{Bahar Baviskar ${ }^{1}$, Kailas Ingle ${ }^{2}$, Priya Gawande ${ }^{3}$, Sachin Raut ${ }^{4}$, Kirty Sirothia ${ }^{5}$ \& Arun Bhandarkar $^{6}$}

${ }^{1} \mathrm{C} / \mathrm{o}$ Shrikrishna V. Baviskar, Retired Judge, Hanuman Galli, Post: Sakali,Yawal, Jalgaon, Maharashtra 425302, India 2,4,5,6 Department of Pathology, Nagpur Veterinary College, M.A.F.S.U., Seminary Hills, Nagpur, Maharashtra 440006, India ${ }^{3} \mathrm{C} / \mathrm{o}$ Jaggannathrao S. Gawande, Gokul Colony, In front of Bhuibhar Gasco, Akola road, Akot, Akola, Maharashtra 444101, India Email: ${ }^{1}$ drbaharbaviskar@gmail.com; ${ }^{2}$ kailashvet@ rediffmail.com; ${ }^{3}$ drpriyagawande @gmail.com; ${ }^{4}$ sachin_raut12@ rediffmail.com; ${ }^{5}$ kirtykirty@ rediffmail.com

Babesiosis, a tick-borne infectious haemoprotozoan disease of cattle, buffaloes, sheep, goats, equines, dogs, cats and wild mammals, is caused by intra erythrocytic piroplasms of the genus Babesia. Generally, this disease is characterized by pyrexia, haemolytic anaemia, haemoglobinuria, jaundice and death. Although sufficient literature is available on babesiosis in domestic animals, meagre information is available on the infection in wild animals This is an attempt to document the first report of Babesia infection in a Nilgai (Boselaphus tragocamelus) from Aarmori, Gadchiroli district, central India.

A male Nilgai (approximately 6-7 years) belonging to forest area of Gadchiroli district was presented for post mortem examination to the Nagpur Veterinary College, Nagpur. Heart blood smears were prepared, stained with Leishman's stain and examined microscopically.

At necropsy the lesions found were enlarged spleen, congestion of liver and kidney and pale mucous membranes indicating severe anaemia which are in agreement with Radostits et al. (2000) who also reported dark brown discolouration of the liver in acute infection of Babesia. The blood smear examination revealed Babesia sp. organisms. Babesiosis has been recognized in many wild animals such as Jackal, Zebra, Reindeer, Spotted Deer, Squarelipped Rhinoceros, Bandicoot (Tripathy et al. 1983), Wild Cat (Mudaliar et al. 1950), and Leopard (Baviskar et al. 2007). A male Mithun (Bos frontalis), of Nandankanan Biological Park,

Date of publication 26 March 2009

ISSN 0974-7907 (online) | 0974-7893 (print)

Editor: Jacob V. Cheeran

Manuscript details:

Ms \# 01829

Received 27 July 2007

Final revised received 26 August 2008

Finally accepted 15 October 2008

Citation: Baviskar, B., K. Ingle, P. Gawande, S. Raut, K. Sirothia \& A. Bhandarka (2009). First report on occurrence of Babesia infection in Nilgai Boselaphus tragocamelus from central India. Journal of Threatened Taxa 1(3): 196.

Copyright: (c) Bahar Baviskar, Kailas Ingle, Priya Gawande, Sachin Raut, Kirty Sirothia \& Arun Bhandarkar 2009. Creative Commons Attribution 3.0 Unported License. JoTT allows unrestricted use of this article in any medium for non-profit purposes, reproduction and distribution by providing adequate credit to the authors and the source of publication.

Acknowledgement: The authors are thankful to the Associate Dean, Nagpur Veterinary College, Nagpur for providing necessary facilities.
Bhubaneshwar, Orissa was also found positive for Babesia sp. and successfully treated with two doses of Diminazine aceturate (Tripathy et al. 1983). Lingard \& Jenning (1904) described spotaneous piroplasmosis in deer belonging to Bareilly area in Uttar Pradesh. Hilpertshauser et al. (2006) conducted a survey of the occurrence of ruminant Babesia sp. in Switzerland in which they identified Babesia sp. organisms from ticks from wild ruminants (Deer, Roe Deer and Chamois) by PCR. The animals was kept in confinement for some period which may have led to stressful condition, which is in consonance with the findings of Penzhorn (2006) who have discussed development of clinical babesiosis in the Black Rhino under stressful conditions like confinement after capture. Disease management views all over the world seem to be changing and diseases among wild animals are being recognized as an important obstacle in wildlife conservation and management. Babesiosis is a widely distributed disease, occurring from the tropics to the Arctic and reports of this disease in wide variety of wild animals are increasing and needs special attention from the management point of view.

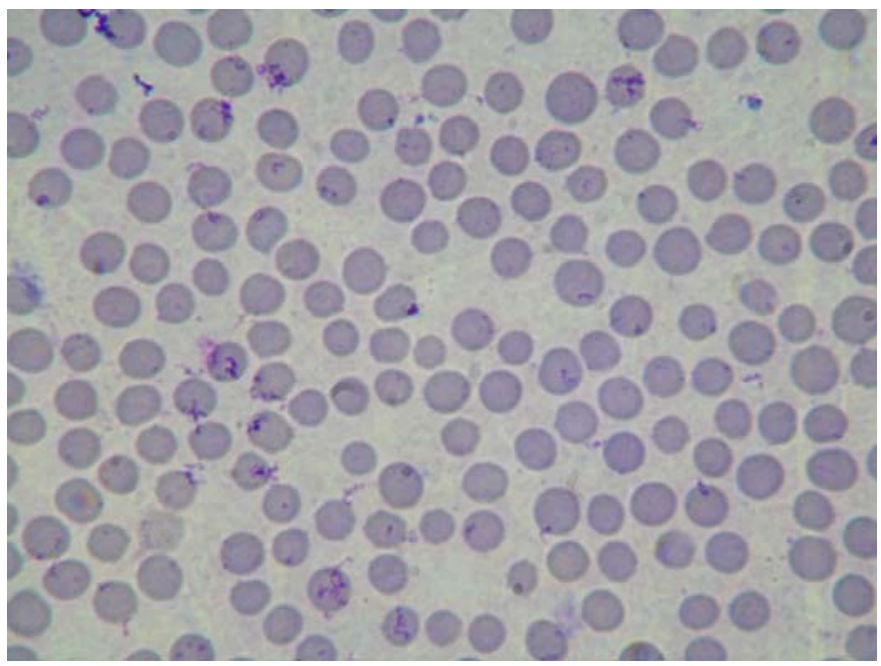

Image 1. Babesia in the red blood cells of Boselaphus tragocamelus

\section{References}

Baviskar B.S., P.J. Gawande, D.K. Maske, A.K. Jayraw, S.S. Bawaskar \& A.G. Bhandarkar (2007). Occurrence of Babesia infection in leopard (Panthera pardus) at Nagpur. Zoos' Print Journal 22(6): 2736-2737.

Hilpertshauser H., P. Deplazes, M. Schnyder, L. Gern \& A. Mathis (2006). Babesia spp. identified by PCR in ticks collected from domestic and wild ruminants in southern Switzerland. Applied Environmental Microbiology 72(10): $6503-6507$

Lingard, A. \& E. Jennings (1904). A preliminary note on a piroplasmosis found in man and in some of the lower animals. Indian Medical Gazette 39: 161-165.

Mudaliar, S.V., G.R. Achary \& V.S. Alwar (1950). On a species of Babesia in an Indian wild cat (Felis catus). Indian Veterinary Journal 26:391-395.

Penzhorn, B.L. (2006). Babesiosis of wild carnivores and ungulates. Veterinary Parasitology 138(1- 2): 11-21.

Radostits O.M., C.C. Gay, D.C. Blood \& K.W. Hinchcliff (2000). Veterinary Medicine A textbook of the Diseases of Cattle, Sheep, Pigs, Goats and Horses. BookPower Publication, 1292pp.

Tripathy, S.B., L.N. Acharjyo \& B.C. Nayak (1983). Babesiosis in a male mithun (Bos frontalis). Indian Journal of Veterinary Medicine 3: 115-116.

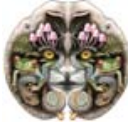

